\title{
PENERAPAN TEKNOLOGI SMART BUILDING PADA PERANCANGAN SMART MASJID
}

\author{
Khalid Abdul Mannan \\ Jurusan Teknik Arsitektur, FSaintek, UIN Maulana Malik \\ Ibrahim Malang \\ e-mail: zloed@yahoo.com \\ Aulia Fikriarini Muchlis \\ Jurusan Teknik Arsitektur, FSaintek, UIN Maulana Malik \\ Ibrahim Malang \\ e-mail: fikriarini@gmail.com
}

\begin{abstract}
Indonesia has the largest Muslim population in the world, followed by a large number of mosques scattered in various places and these mosques sometimes have a problem regarding the efficiency in managing the resources of a mosque. This paper is designed to introduce the concept of mosque design based on the principles of smart building with the literature study methods and analysis, and comparison to the values in the philosophy of the Qur'an to determine the suitability of the application of smart building technology in the design of a mosque. With the support of some religious activities program, the expected result is "smart mosque", that would also suit with the site and user.
\end{abstract}

Keywords: mosque, smart building

\begin{abstract}
Abstrak
Indonesia merupakan negara dengan penduduk muslim terbanyak di dunia. Walaupun demikian, di balik jumlahnya yang banyak, sering dijumpai permasalahan menyangkut efisiensi dalam pengelolaaan sumber daya sebuah masjid. Tulisan ini dibuat untuk mengenalkan konsep perancangan masjid berdasarkan prinsip-prinsip smart building, dimana smart building adalah teknologi untuk mengangkat tingkat efisiensi dalam pengelolaan sebuah bangunan. Metode yang digunakan adalah studi literatur dan analisis, disertai komparasi dengan nilainilai perancangan dalam al-Qur'an untuk menentukan tingkat kesesuaian penerapan teknologi smart building dalam perancangan sebuah masjid. Hasilnya adalah teknologi smart building sesuai untuk diterapkan dalam perancangan masjid.
\end{abstract}

Kata kunci: masjid, smart building

\section{Pendahuluan}

Indonesia merupakan negara dengan penduduk muslim terbanyak di dunia. Pertumbuhan penduduk muslimnya yang pesat berpengaruh terhadap jumlah masjid di Indonesia yang tumbuh dengan pesat pula. Dengan jumlah penduduk muslim di tahun 2012 yang mencapai $88 \%$ atau sekitar 210 juta dari 240 juta penduduk Indonesia, kini terdapat sekitar 600 ribu masjid di Indonesia dengan pertumbuhan mencapai $60 \%$ per tahun.

Walaupun demikian, di balik jumlahnya yang banyak, sering kita jumpai permasalahan menyangkut esensi dan nilai dalam perancangan sebuah masjid. Hal ini antara lain dipengaruhi oleh cara pandang seorang arsitek dalam memahami filosofi dari sebuah masjid. Apabila dalam perancangannya masjid dipahami sebagai rumah Tuhan, implikasi yang muncul adalah perlombaan untuk merancang masjid yang terbesar, termahal, terbaik, ataupun terindah ${ }^{1}$. Kemewahan arsitektur masjid seringkali dijadikan simbol kesyukuran atas rahmat Allah swt., yang sebenarnya kontradiktif dengan anjuran untuk tidak berlebih-lebihan dan menonjolkan diri ${ }^{2}$.

Dengan demikian, dapat disimpulkan bahwa masjid yang baik bukanlah masjid yang indah dari bentuknya saja, namun juga benar, sesuai nilai-nilai ajaran Islam yang terkandung dalam al-Qur'an dan Hadits. Oleh karena itu, pendekatan yang sesuai untuk dipakai dalam perancangan masjid adalah pendekatan kontekstual, dimana isu ataupun permasalahan yang ada menjadi hal yang diangkat untuk diselesaikan melalui perancangan sebuah masjid. Permasalahan tersebut antara lain mencakup permasalahan sosial seperti kemiskinan dan tingginya angka pengangguran serta permasalahan lingkungan seperti global warning dan efek rumah kaca. 
Terkait hal tersebut, teknologi smart building dapat menjadi alternatif solusi untuk penyelesaian masalah lingkungan dalam perancangan sebuah masjid. Teknologi smart building mampu mengangkat tingkat efisiensi pengelolaan dalam sebuah bangunan, sehingga sesuai untuk mengurangi konsumsi energi yang digunakan dalam aktivitas sebuah masjid. Selain itu banyak persamaan antara prinsip-prinsip dari teknologi smart building dengan nilai-nilai ajaran Islam seperti kemanfaatan, efisiensi, dan ketidak-mubaziran. Hal ini secara tidak langsung dapat menjadi contoh penerapan nilai-nilai ajaran Islam secara langsung, sehingga masyarakat ke depannya diharapkan dapat lebih menerima dan mengerti arti sesungguhnya dari nilai-nilai ajaran Islam tersebut.

\section{Metode}

Metode yang digunakan adalah studi literatur pada tema dan objek yang dibahas, yakni masjid dan smart buidling. Hasil dari studi literatur kemudian dikomparasikan dengan nilai-nilai ajaran Islam dalam al-Qur'an untuk menentukan tingkat kesesuaian antara teknologi smart buildingdengan nilai-nilai ajaran Islam. Hasil dari komparasi tersebut berupa prinsip-prinsip dasar smart building yang sesuai dengan nilai-nilai ajaran Islam.

Selanjutnya, prinsip-prinsip tersebut digunakan sebagai acuan dalam studi banding pada rancangan masjid-masjid yang sudah ada. Dari hasil studi banding nantinya diperoleh jenis teknologi smart building apa saja yang sesuai untuk diterapkan dalam perancangan sebuah masjid.

\section{Hasil dan Diskusi}

Istilah masjid memiliki akar kata dari bahasa Aram. Kata masgid (m-s-g-d) dalam bahasa Aram berarti tiang suci atau tempat sembahan, ditemukan dalam sebuah inskripsi dari abad ke-5sebelum masehi. Kata masjid dalam bahasa Inggris disebut mosque yang berasal dari kata mezquita dalam bahasa spanyol yang kemudian populer dan dipakai dalam bahasa Inggris secara luas ${ }^{3}$.

Istilah masjid sendiri secara terminologis berarti suatu badan atau institusi yang diperuntukkan sebagai pusat ibadah dari orang-orang mukmin, dimana sentral kegiatan mereka berpusat disana, mulai dari kegiatan menghambakan diri kepada Allah swt sampai kepada perjuangan hidup yang berdimensi dunia semata. Dr Makhmud Syafi'e dalam tulisannya "Perspektif Sejarah dan Hukum Islam"4 menyebutkan bahwa mengingat akar kata masjid bermakna tunduk dan patuh, maka hakikat masjid itu adalah tempat melakukan segala aktivitas ibadah sebagai manifestasi dari ketaatan kepada Allah semata.

Ditinjau dari jenisnya, ibadah dalam Islam terbagi menjadi dua, dengan bentuk dan sifat yang berbeda antara satu dengan lainnya. Umay $M$. Dja'far Shiddieq memaparkan bahwa ibadah ditinjau dari jenisnya terbagi menjadi dua jenis, yaitu ibadah mahdah dan ibadah ghairu mahdah. Ibadah mahdhah atau ibadah khusus adalah ibadah yang ketentuannya akan tingkat, tata cara dan perincian-perinciannya telah ditetapkan oleh Allah swt. Jenis ibadah yang termasuk ibadah mahdhah adalah wudhu, tayammum, mandi hadats, shalat, shiyam, haji dan umrah. Sedangkan ibadah ghairu mahdhah atau ibadah umum adalah segala amalan yang diizinkan oleh Allah.Contoh ibadah ghairu mahdhah adalah belajar, dzikir, tolong menolong dan lain sebagainya.

Dalam penerapannya, ibadah ghairu mahdah mencakup ke dalam seluruh perbuatan baik yang dilakukan dengan niat untuk mencari ridha dari Allah. Maka, apabila dalam masjid digunakan teknologi terbaru yang bermanfaat dengan niat baik maka hukum penggunaanya adalah mubah, karena sifatnya yang termasuk ke dalam kategori ibadah maghdah.

Smart building sendiri sebenarnya bukanlah hal baru dalam dunia konstruksi atau pembangunan. Smart buildingsystem atau mungkin juga biasa disebut intelligent building system adalah sebuah integrasi teknologi dengan instalasi bangunan yang memungkinkan seluruh perangkat fasilitas gedung dapat dirancang dan diprogram sesuai kebutuhan, keinginan, dan kontrol otomatis terpusat. Banyak sekali perbedaan pendapat mengenai pengertian smart building. Untuk itu dalam bukunya Intelligent Buildings and Automation, Shengwei Wang membaginya ke dalam 3 kategori yang terdiri dari:

\section{a. Performance Based Definitions}

Dengan mengoptimalkan performa bangunan yang dibuat untuk efisiensi lingkungan dan pada saat itu juga mampu menggunakan dan mengatur sumber energi bangunan dan meminimalkan life cost perangkat dan utilitas bangunan. Smart building menyediakan efisiensi tinggi, kenyamanan dan kesesuaian dengan lingkungan dengan mengoptimalkan penerapan struktur, sistem, servis dan manajemen. Smart building juga harus mampu beradaptasi dan memberikan respon cepat dalam berbagai perubahan kondisi internal maupun external dan dalam menghadapi tuntutan users.

\section{b. Services Based Definitions}

Dalam tujuan utamanya bangunan harus mampu menyediakan kualitas servis bagi user. Japanese Intelligent Building Institute (JIBI) mendefinisikan smart building atau intelligent building adalah sebuah bangunan dengan fungsi servis komunikasi, otomatisasi bangunan dan mampu menyesuaikan dengan aktivitas user. Di Jepang 4 aspek layanan servis dibagi menjadi 4 sesuai dengan key issue smart building yaitu:

1. Layanan dalam menerima dan menghubungkan informasi serta mendukung efisiensi control manajemen

2. Menjamin kepuasan dan kenyamanan user yang bekerja atau berada di dalamnya

3. Merasionalkan manajemen bangunan dalam menyediakan layanan administrasi yang murah.

4. Perubahan yang cepat, fleksibel dan ekonomis dalam responnya terhadap sosiologi lingkungan, 
komplektivitas dan bermacam-macamnya tuntutan pekerjaan serta strategi bisnis.

\section{c. System Based Definitions}

Smart building harus memiliki sebuah teknologi dan system teknologi yang digabungkan. Chinese Intelligent Building Design Standard mengeluarkan standar yang harus dimiliki smart building yaitu menyediakan otomatisasi bangunan, system jaringan komunikasi, optimalisasi integrasi komposisi dalam struktur, sitem, servis, manajemen dalam menyediakan efisiensi tinggi, kenyamanan dan ketenangan bagi users.

Dari uraian di atas dapat disimpulkan bahwa bangunan smart building atau intelligent building haruslah memenuhi aspek-aspek perancangan seperti:

1. Menyediakan informasi dan mengoptimalkan performa building system dan fasilitas.

2. Aktif dalam memonitor dan mendeteksi kesalahan dan kekurangan dalam building systems.

3. Mengintegrasikan system untuk dalam kegiatan bisnis, real time report dan manajemen operasi utilitas, energy dan kenyamanan users.

4. Menggabungkan tools, teknologi, sumber energy dan layanan dalam mengkontribusikan konservasi energy dan sustainability atau keberlanjutan lingkungan.

\section{Penerapan Smart Building dalam Bangunan}

Dalam smart building melibatkan berbagai instalasi dan penggunaan kecanggihan dan terintegrasi dalam system teknologi bangunan. Sistem ini mencakup otomatisasi bangunan, keamanan, telekomunikasi, sistem pengguna, dan sistem manajemen fasilitas. Smart Building mengenali dan menunjukkan kemajuan teknologi dan konvergensi sistem bangunan, unsur-unsur umum dari sistem dan fungsionalitas tambahan bahwa sistem telah terintegrasi. Smart building memberikan tindak lanjut informasi mengenai bangunan atau ruang dalam bangunan untuk memungkinkan pemilik bangunan atau penghuni mengelola gedung dan ruang.

Smart building memberikan pendekatan yang paling efektif dalam mendesain dan dalam membangun system teknologi. Cara konvensional merancang dan membangun sebuah bangunan namun mengoperasikan system secara terpisah. Artinya kurang ada kerjasama antara semua sub-sistem sehingga sistem yang ada secara keseluruhan menjadi tidak. Lebih jauh dijelaskan pada gambar di bawah ini:

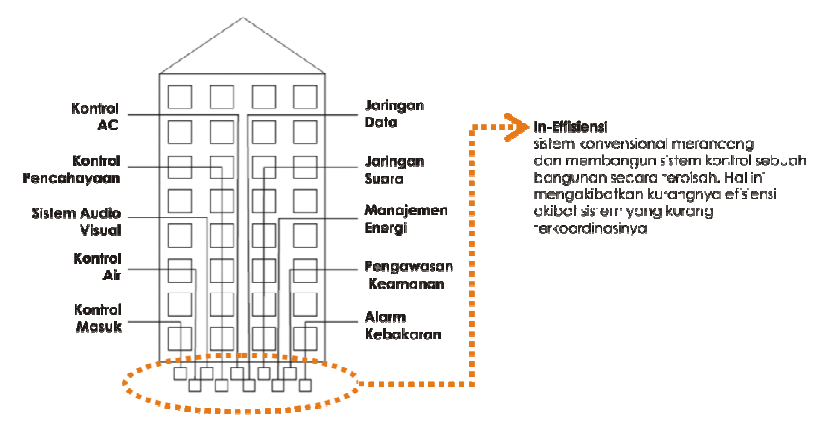

Gambar 1.1. Sistem Kontrol Teknologi Bangunan Konvensional (sumber: Sinopoli, 2010:3)

Smart building mengambil pendekatan yang berbeda dalam merancang sebuah sistem. Pada dasarnya, satu desain atau koordinat dari seluruh desain bangunan bersistem teknologi termasuk ke dalam dokumen konstruksi yang terpadu dan konsisten. Dokumen konstruksi menentukan setiap sistem dan alamat sistem elemen umum atau sebuah integrasi untuk sistem. Ini termasuk kabel, jalur kabel, peralatan kamar, database sistem, dan komunikasi protokol antar perangkat. Salah satu desain konsolidasi ini kemudian dipasang oleh kontraktor, disebut sebagai Kontraktor Teknologi atau sebagai Master System Integrator.

Proses ini mengurangi ineffisiensi dalam proses desain dan konstruksi, menghemat waktu dan uang. Selama operasi bangunan, bangunan sistem teknologi yang terintegrasi secara horizontal antara semua subsistem maupun vertikal, yang subsistem dalam sistem manajemen fasilitas bisnis memungkinkan system informasi dan data operasi gedung digunakan oleh beberapa individu yang menempati dan mengelola bangunan. Lebih jauh mengenai penjelasan smart building system dijelaskan pada gambar berikut ini:

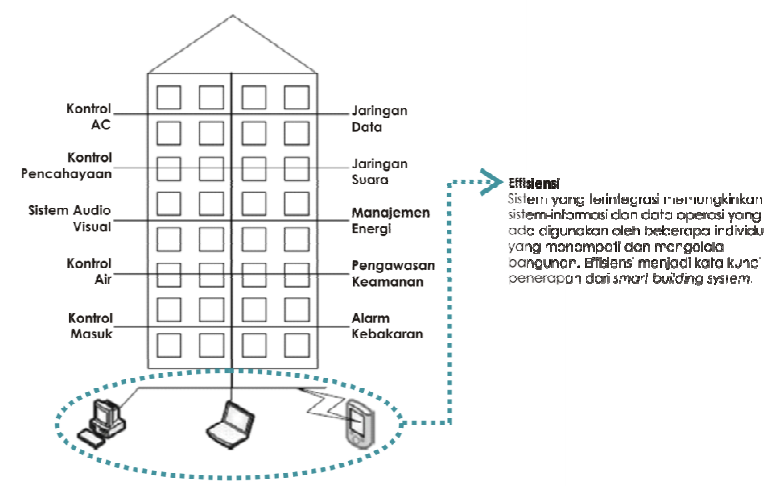

Gambar 2.19. Penerapan Integrated Building System pada Smart Building (sumber: Sinopoli, 2010:4)

Smart Building juga memiliki komponen penting mengenai penggunaan energi dan sustainable bangunan dan jaringan smart elektrical. Otomatisasi bangunan sistem, seperti kontrol HVAC, pencahayaan kontrol, manajemen daya, dan 
metering memainkan peran utama dalam menentukan efisiensi energi operasional bangunan. Jaringan smart elektrical erat dengan Smart Building. Kekuatan pendorong untuk Smart Building economic, energy, dan technology. Smart dalam memanfaatkan infrastruktur teknologi informasi bangunan utama dan mengambil keuntungan dari teknologi yang ada. Untuk pengembang dan pemilik, smart building meningkatkan nilai properti. Untuk properti dan manajer fasilitas, smart building menyediakan subsistem yang lebih efektif dan lebih efisien dalam manajemen, seperti konsolidasi sistem manajemen. Untuk arsitek, insinyur, dan kontraktor konstruksi, itu berarti menggabungkan bagian-bagian dari desain dan konstruksi yang dihasilkan dan efisiensi dalam manajemen proyek dan penjadwalan proyek.

\section{Kesimpulan: Prinsip-Prinsip Dasar Smart Building}

Dari penjabaran diatas dapat disimpulkan prinsip-prinsip dasar dari smart building terkait perancangan masjid sebagai tempat ibadah. Prinsipprinsip tersebut adalah :

\section{a. Efisiensi}

Salah satu tolak ukur keberhasilan suatu bangunan dalam menerapkan tema smart building adalah apabila bangunan tersebut sudah efisien dalam pengelolaannya. Dalam kaitannya dengan perancangan smart masjid, prinsip efisiensi dapat diterapkan mulai dari pemilihan lokasi, perencanaan material, perencanaan pembangunan, perencanaan sistem utilitas, hingga perencanaan desain bentuk bangunan.

b. Efektif

Prinsip efektif dalam smart building berarti penerapan teknologi yang tepat guna, dimana alat ataupun material yang dipilih sesuai dengan yang dibutuhkan. Secara filosofis hal ini berarti ketepatan antara jawaban yang diberikan atas persoalan yang ada. Dalam perancangan smart masjid ini, prinsip efektif dapat diterapkan di seluruh aspek perancangan, terutama diterapkan pada hasil akhir desain masjid, yang diharapkan mampu sejalan dengan masalah yang menjadi issue yang ingin diselesaikan melalui perancangan masjid ini.

\section{c. Kemudahan}

Mudah dalam hal ini berarti mudah dalam mengoperasikan, mudah dalam perawatan, serta sistem yang ada mudah untuk ditiru dan dikembangkan ditempat lain dimana dalam perancangan smart masjid ini diharapkan dapat menjadi protoype, percontohan bagi masjid-masjid lainnya dalam mengembangkan dan membuat masjid yang efektif dan efisien. Dengan demikian, bangunan masjid akan menjadi media pembelajaran tak langsung, dimana masyarakat yang ada diharapkan dapat mengambil pelajaran dari sistem yang ada.

\section{d. Penerapan Teknologi Terbaru}

Penerapan teknologi terbaru berarti menanamkan semangat kebaruan dimana kita diajak untuk terus belajar dan mencari hal-hal yang baru yang sekiranya berguna bagi lingkungan dan masyarakat sekitar. Penerapan prinsip ini yakni pada pencarian inovasi yang bermanfaat, yang nantinya digunakan sebagai bagian dari perancangan smart masjid ini.

Itulah empat hal yang menjadi tolak ukur penerapan prinsipsmart building dalamperancangan objek bangunan masjid ini. Satu hal yang penting adalah prinsip-prinsip tersebut akan menjadi satu kesatuan yang baik apabila seluruh sistem yang dipakai dapat diintegrasikan menjadi sebuah sistem besar yang terpadu.

\section{Referensi}

1 Rasdi, Mohammad Tajuddin. 2010. Rekabentuk Masjid Sebagai Pusat Pengembangan Masyarakat. Malaysia: Desktop Publisher

2 Putrie, Yulia Eka. 2009. Kontradiksi Simbol dan Substansi Nilai Islam dalam Arsitektur Masjid. Lembaga Penelitian dan Pengembangan UIN Malang. Laporan Penelitian Tidak Diterbitkan.

3 http://wikipedia.org/wiki/masjid

4 Syafi'ie, Makhmud. Tt. Perspektif Sejarah dan Hukum Islam. unpublished 